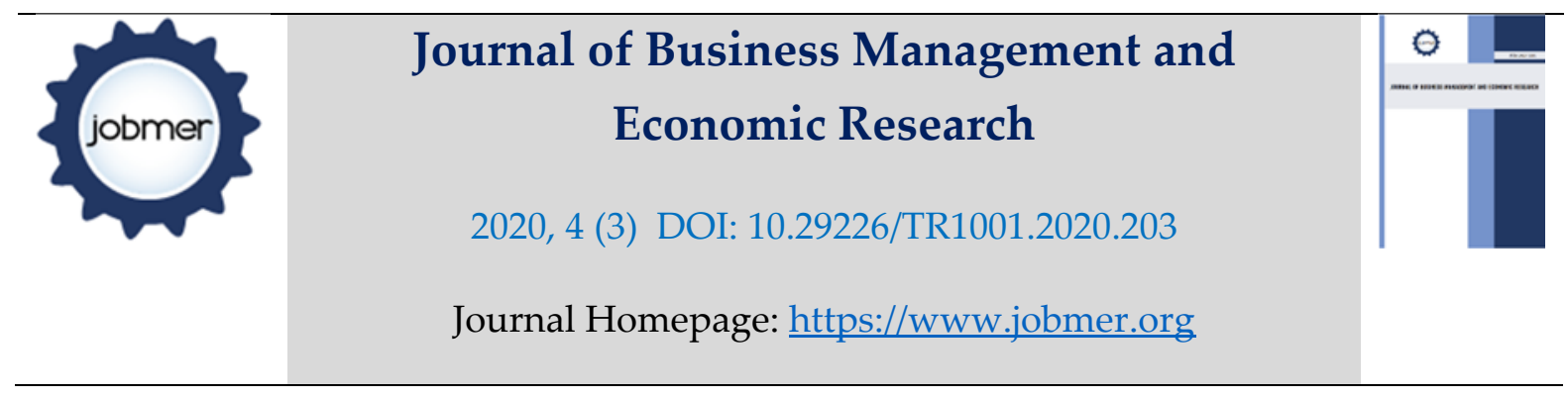

\title{
DO CAPITAL STRUCTURE HAS AN EFFECT ON AGENCY COSTS? EVIDENCE FROM KENYAN LISTED FIRMS
}

\author{
Thomas Kiptanui Tarus \\ School of Business and Economics, Moi University Kenya \\ tarus9116@gmail.com
}

\begin{abstract}
The main purpose of the article was to determine whether the capital structure has an effect on agency costs. The agency theory was used as the central theoretical analysis of the research. The study used 34 listed firms in the Nairobi Securities Exchange being firms that revealed consistency in the market during the period 2006-2012 giving a total of 238 firm-year observation. The study used a linear regression model to analyze data with the support of SPSS software. The results indicated that capital structure was negatively and significantly correlated to agency $\operatorname{cost}(\mathrm{r}=-0.464 ; p<0.01)$ at a $1 \%$ confidence interval level. The study findings will be of valuable assistance to shareholders of listed firms in the Nairobi Securities Exchange in maintaining the leverage at a controlled level.
\end{abstract}

Keywords: Capital Structure, Agency Cost, Agency Theory

\section{Suggested Citation:}

Tarus, T. K. (2020). Do capital structure has an effect on agency costs? Evidence from Kenyan listed firms. Journal of Business Management and Economic Research (JOBMER), Vol: 4, Issue:3, 245-252.

\section{Introduction}

Agency problems are increasingly inherent in the modern-day corporation, owing to the widening separation of ownership and control responsibilities, growing business diversification and segmentation across industry and business lines. Agency costs manifest in various circumstances including self-serving behaviors on the part of managers focused on empire-building objectives, excessive perquisite consumption, non-optimal investment decision making and or acts of accounting mismanagement (Henry, 2004).

According to Ang et al., (2000) they argued that higher leverage may reduce agency costs through the monitoring activities by debt holders however the threat of liquidation may cause managers to lose reputation, salaries, etc. As the proportion of debt in the capital structure increases beyond a certain point, the opposite effect of leverage on agency costs may occur (Altman, 1984). Three reasons are 
identified in the literature which can cause this opposite effect: The first reason is the increase in bankruptcy costs (Titman, 1984). The second reason is that managers may reduce their effort to control risk which results in higher expected costs of financial distress, bankruptcy, or liquidation (Berger and Bonaccorsi, 2005). Finally, inefficient use of excessive cash used by managers for empire-building would also increase agency costs (Jensen, 1986)

The agency costs associated with debt consist of the opportunity wealth loss, which is caused by the impact of debt on investment decisions of the firm, bankruptcy costs and monitoring and bonding expenditures (Jensen and Meckling, 1976). Debt holders do not only share profits and earnings with equity holders but also have a fixed claim on cash flows, which is the interest of the debt. This conflict between equity holders and debt holders may affect a firm's decisions on three dimensions: investment, financing strategy and dividend distribution (De Marzo and Fishman, 2007). Debt holders may restrict the manager's investment on risky projects even though they may bring high returns (Kalcheva and Lins, 2007).

Zheng. M. (2013) postulates that capital structure plays important role in determining the agency costs arising from the conflicts of interest between debt holders and shareholders, a role which has not been extensively analyzed previously in the academic literature. He also states that the use of debt could reduce the agency cost under an effective debt policy. Because too much debt will lead to bankruptcy risk of a firm, so with paying the initial payment and interest cost at the due time could reduce the risk of managers using the cash flow to finance other things that are not aligned with the maximization of shareholder value. Managers will be forced to fulfill the duty of paying the debt, so it will reduce the cash flow and also the agency cost.

Listed firms can only achieve their objectives and effectively discharge their responsibilities if they are led by quality and effective capital structure decisions. Listed firms' failures have been attributed to the bad corporate decision. Conflicting results are observed in regards to the relationship between firm size and agency costs, although different factors are found to impact on the level of agency costs for small and large firms. This paper, therefore, seeks to establish the effect of capital structure on agency cost among listed firms in the Nairobi Securities Exchange in addressing the research problem.

\section{Literature Review}

\subsection{Theory development}

In agency theory, Jensen and Meckling (1976) identify agency costs derived from conflicts between equity holders and owner-managers as residual loss which means that agents consume various 
pecuniary and non-pecuniary benefits from the firm to maximize his own utility. Related to this, Childs et al. (2005) and Lee et al. (2004) argued that managers always want to continue the firm's current operations even if liquidation of the firm is preferred by investors. Also, Alvarez et al., (2006) and Kent et al., (2004) suggested that managers always want to invest all available funds even if paying out cash is better for outside shareholders, and conflict between the manager and equity holders cannot be resolved through contracts based on cash flows and investment expenditures.

Agency theory becomes more complicated when debt holders' interest is considered. As a financing strategy, debt is widely discussed in capital structure literature. Modigliani and Miller (1963) demonstrate that in order to raise the value of a firm, the amount of debt financing should be as big as possible for a tax subsidy. However, their theory ignores the agency costs of debt. Theoretically, Jensen and Meckling (1976) point out that the optimal utilization of debt is when the debt is utilized to the point where marginal wealth benefits of the tax subsidy are just equal to the marginal wealth effects of agency

\subsection{Empirical reviews}

According to Cao (2006), findings revealed that the total asset turnover has a negative relationship toward agency cost. More findings by Ellul (2005), Wang (2010) and Wellalage (2012) found that the debt ratio has a positive relationship with agency cost. They further found that the use of debt is intended to expand the company's operational activity which may lead to an increased operational expense. However, the choice of debt financing will lead to another conflict between shareholders and bondholders. Sanvicente and Bortoluzzo (2013) found in their study that there was no significant relationship between debt ratio and agency cost. Khan et al. (2012) also found that long term debt ratio has no significant effect on agency cost

Zheng. M, (2013) found in his research that long term debt ratio has a negative correlation with agency cost. The use of long-term debt potentially reduces agency costs because the managers will just focus on generating profit for the company to pay the long term liabilities of the company. However, Ellul (2005) and Lin (2006) found that long term debt ratio has a positive correlation with the agency cost.

\section{Research Methodology}

This study adopted an explanatory research design that establishes causal relationships. The design was best for ascertaining the effect of capital structure on agency cost among listed firms at the Nairobi Securities Exchange in Kenya. Secondary data through documentary guide analysis was used to 
facilitate data collection among selected listed firms. The target population was the published financial statements of the listed firms in Kenya. There were 34 listed firms in the Nairobi Securities Exchange being firms that have shown consistency in the market during the seven-year period between 2006 to 2012 giving a total of 238 firm-year observations.

\subsection{Measurement of Variables}

Dependent Variable: Agency cost was measured using two proxies: First, Asset utilization which was measured as the ratio of annual total revenue to annual total assets as used by Ang et al., (2000) and Singh and Davidson III (2003). This provides the relative quantitative measure of the effectiveness of firm investment decisions and the ability of the firm's management to direct assets to the most productive use. The second proxy was discretionary expenditure ratio measured as annual selling, general and administrative expenditure divided by annual total revenue to establish relative expenditure on items over which management has discretionary authority Singh and Davison III (2003). Further, a composite measure of the two variables was computed to measures the overall agency cost.

Independent variable: The capital structure was measured as the ratio of debt to equity (Rafique, 2010).

\section{Results}

The study utilized a quantitative technique to analyzed data using descriptive inferential statistics. Descriptive statistics include the mean, mode, and standard deviation while inferential statistics include the Pearson Correlation. The data collected was analyzed using linear regression and correlation analysis and the significance of the independent variable was tested at a confidence level of $95 \%$.

\subsection{Descriptive statistics}

The descriptive statistics are presented in Table 4.1 which indicated that the mean value of agency cost is 1.3124 and that of capital structure is 0.6107 . The highest and lowest values for agency costs are 0 and 5.66 and that of capital structure is 0 and 3.19. Further, both Skewness and Kurtosis approaches zero hence normal distribution, so the farther away from zero, the more non-normal the distribution. Also using the rule of thumb which states that a variable is reasonably close to normal if its skewness and kurtosis have values between -1.0 and +1.0 , thus the study variables are normally distributed. 
Table 4.1 Descriptive Statistics

\begin{tabular}{lllllll}
\hline & Minimum & Maximum & Mean & Std. Deviation & Skewness & Kurtosis \\
\hline Agency cost & 0 & 5.66 & 1.3124 & 1.34069 & 0.104 & 0.27 \\
Capital structure & 0 & 3.19 & 0.6107 & 0.61399 & 0.375 & 0.479 \\
\hline
\end{tabular}

\section{Source: Author}

\subsection{Correlation Results}

The main purpose of the correlation matrix is to assess whether the relation between capital structure and agency cost is statistically significant. As evidenced in Table 4.2, capital structure was negatively correlated to agency $\operatorname{cost}(\mathrm{r}=-.464)$. Correlation between capital structure and agency cost was indicated to be significant at 0.01 confidence interval level, hence it is inferred that there was a negative significant relationship between capital structure and agency cost.

Table 4.2 Correlation Matrix

\begin{tabular}{lll}
\hline & Agency cost & Capital structure \\
\hline Agency cost & 1 & \\
Capital structure & $-0.464^{* *}$ & 1 \\
\hline
\end{tabular}

** Correlation is significant at the 0.01 level (2-tailed).

\section{Source: Author}

\section{Model Summary}

The findings in Table 4.3 revealed capital structure explains $21.5 \%$ of the variation in agency cost as represented by the $R^{2}=0.215$ which means that the suggested model is able to predict about $21.5 \%$ of the change in agency cost. This means that the variables in the linear equation possess relatively weak predictive power and that the model itself has less predictive capability. Durbin Watson test showed that there was no autocorrelation among the variable as indicated by value 1.43 which was less than 2 thumb rule.

Table 4.3 Model Summary

\begin{tabular}{|c|c|c|c|c|}
\hline $\mathrm{R}$ & R Square & Adjusted R Square & $\begin{array}{l}\text { Std. Error of the } \\
\text { Estimate }\end{array}$ & Durbin-Watson \\
\hline $.464 a$ & 0.215 & 0.211 & 1.19078 & 1.43 \\
\hline
\end{tabular}

\section{Source: Author}




\section{ANOVA Model}

The study used Analysis of Variance (ANOVA) to test the relationships since ANOVA removes some of the random variability so that significant differences can be found more easily and also helps to look at interactions between factors. The results in Table 4.4 indicated that $F$ value 56.4 , with $p<0.05$ significant at 0.05 implying that the model is statistically significant in predicting agency cost.

Table 4.4 ANOVA Model

\begin{tabular}{llllll}
\hline & Sum of Squares & Df & Mean Square & F & Sig. \\
\hline Regression & 79.973 & 1 & 79.973 & 56.4 & $.000 \mathrm{~b}$ \\
Residual & 292.099 & 206 & 1.418 & & \\
Total & 372.072 & 207 & & & \\
\hline
\end{tabular}

a Dependent Variable: Agency cost

b Predictors: (Constant), Capitals structure

\section{Source: Author}

\subsection{Hypothesis testing}

The results in table 4.5 below showed that the standardized coefficient beta and p-value of capital structure were negative and significant $(\beta=-0.464, \mathrm{p}<0.05)$. This implies that for each unit increase in capital structure, there is a 0.464 unit decrease in agency costs. The effect of capital structure is shown by the t-test value of -7.51 which implies that the effect of capital structure surpasses that of the error by over seven times. The findings were in conformity with Cao (2006) assertion that the total asset turnover is negatively associated with agency costs. Similarly, Zheng M (2013) found in his research that long term debt ratio is negatively correlated with agency cost though Ellul (2005) and Lin (2006) were of the contrary. Nonetheless, the use of debt with an intention to expand a firm's operational activity results in conflict between debt ratio and agency cost (Wellalage, 2012). In this light, Wellalage (2012) found a positive relationship between debt ratio and agency cost.

Table 4.5 Coefficient of Estimate

\begin{tabular}{llllll}
\hline & \multicolumn{2}{l}{ Unstandardized Coefficients } & \multicolumn{2}{c}{ Standardized Coefficients } \\
\hline & B & Std. Error & Beta & T & Sig. \\
\hline (Constant) & 1.931 & 0.117 & & 16.559 & 0.000 \\
Capital structure & -1.012 & 0.135 & -0.464 & -7.51 & 0.000 \\
\hline
\end{tabular}

a Dependent Variable: Agency cost

Source: Author 


\section{Conclusion and Recommendation for Further Research}

In light of the findings, the negative relation between capital structure and agency costs was confirmed. The results clearly indicated that the use of debt reduces agency costs since managers are able to dedicate their attention to generating profit in order to meet the long term liabilities and obligations of the firm. However, debt financing leads to conflicts between shareholders and bondholders. More so an increase in leverage results in a decline in agency costs. This is as a result of monitoring activities by debt holders. As such, there is a need for listed firms in the Nairobi Securities Exchange to maintain the leverage at a controlled level since when it becomes relatively high, it may switch to the opposite relation. Also, the company's cash that has increased due to debt needs to be drained in order to prevent managers from acting in defiance to shareholders by maximizing their own interest. Areas of further research that were identified include a similar study to be carried out but increase the number of firms and period of study. Also, including moderator factors can also be made by scholars in the future. This way, future scholars can complement this result to obtain further insight into this research area.

\section{References}

Altman, Edward, (1984). A further empirical investigation of the bankruptcy cost question, Journal of Finance 39, 1067-1089.

Alvarez, H.; J. Virtanen, (2006), A class of solvable stochastic dividend optimization problems: on the general impact of flexibility on valuation, Economic Theory, 28,pp373-398.

Ang, J.S., R.A. Cole and J. Wuh Lin, (2000). Agency costs and ownership structure, Journal of Finance. 55: 81-106

Berger S., E. Banaccorsi di Patti, (2005), Capital Structure and firm performance: A new approach to testing agency theory and an application to the bank industry, Journal of Banking \& Finance, 30, 1065-1102.

Cao, B. (2006). Debt Financing and the Dynamic of Agency Cost. Dissertation, University of California, San Diego.

Childs, P. D., Mauer, D. C., \& Ott, S. H. (2005). Interactions of corporate financing and investment decisions: The effects of agency conflicts. Journal of financial economics, 76(3), 667-690.

De Marzo, P. M., and M. J. Fishman. (2007). Agency and Optimal Investment Dynamics. Review of Financial Studies 20:151-88

Ellul Andrew. (2005). External Governance and Debt Agency Costs of Family Firms, Research Paper Series, Kelley School of Business, Indiana University.

Henry, D., (2004). Corporate governance and ownership structure of target companies and the outcome of takeover bids"e, Pacific-Basin Finance Journal 12, 419-444.

Jensen, M. C., (1986), Agency cost of free cash flow, corporate finance and takeovers. American Economic Review, 76, 323-339.

Jensen, M.C. and Meckling, W.H. (1976). Theory of the firms: managerial behavior, agency costs and ownership structure: Journal of Financial Economics. 3(4): 305-60. 
Kalcheva, I., and K. Lins. (2007). International Evidence on Cash Holdings and Expected Managerial Agency Problems. Review of Financial Studies 20:1087-112.

Kent. B., M. Smith, (2004), In search of a residual dividend policy, Review of Financial Economics, 15(1) 118.

Khan, M.K. (2012). Impact of Firm Capital Structure Decisions on Debt Agency Problem: Evidence for Pakistan, Journal of Basic and Applied Scientific Research, 2(8): 7897-7905

Lee, P. M., H. M. O'Neill, (2004), Ownership Structures and R\&D Investments of U.S. and Japanese Firms: Agency and Stewardship Perspectives, Academy of Management Journal, 46,

Lin, K.L. (2006). Study on Related Party Transaction with Mainland China in Taiwan Enterprises. Dissertation, Management Department, Guo Li Cheng Gong University, China.

Modigliani, F. and M. Miller, (1963), Corporate income taxes and the cost of capital: American Economic Review, 53, pp433-43.

Rafique, M. S. (2010), _Fiscal Stance, The Current Account and The Real Exchange Rate: Some Empirical Estimates from a Time-Varying Framework', Structural Change and Economic Dynamics, 21: 276 290.

Sanvicente, A.Z \& Bortoluzzo, A.B, (2013). Agency Costs, Capital Structure Decisions and the Interaction with Payout Decisions: Empirical Evidence from Brazil.

Singh, M. and W.N. Davidson III, (2003). Agency costs, ownership structure and corporate governance mechanisms, Journal of Banking and Finance. 27: 793-816.

Titman Sheridan, (1984). The effect of capital structure on a firm's liquidation decision, Journal of Financial Economics 13, 137-151

Wang, G.Y. (2010). The Impacts of Free Cash Flows and Agency Costs on Firm Performance, Journal Service Science and Management, 3: 408-418

Wellalage, N.H. (2012). An Empirical Investigation of Agency Costs and Ownership Structure in Unlisted Small Businesses, New Zealand Journal of Applied Business Research, 10(2).

Zheng, M. (2013). Empirical Research of the Impact of Capital Structure on Agency Cost of Chinese Listed Companies, International Journal of Economics and Finance, 5(10): 1916-9728. 